\title{
Fluoride in the Serra Geral Aquifer System: Source Evaluation Using Stable Isotopes and Principal Component Analysis
}

\author{
Arthur Schmidt Nanni, ${ }^{1}$ Ari Roisenberg, ${ }^{2}$ Maria Helena Bezerra Maia de Hollanda, ${ }^{3}$ \\ Maria Paula Casagrande Marimon, ${ }^{4}$ Antonio Pedro Viero, ${ }^{2}$ and Luiz Fernando Scheibe ${ }^{1}$ \\ ${ }^{1}$ Universidade Federal de Santa Catarina (UFSC), Campus Universitário, Trindade, 88.010-970 Florianópolis, SC, Brazil \\ ${ }^{2}$ Universidade Federal do Rio Grande do Sul (UFRGS), Avenida Bento Gonçalves 9500, prédio 43126/103, \\ 91501-970 Porto Alegre, RS, Brazil \\ ${ }^{3}$ Centro de Pesquisas Geocronológicas (CPGeo), Instituto de Geociências (USP), Universidade de São Paulo (USP), \\ Rua do Lago 562, Cidade Universitária, 05508-080 São Paulo, SP, Brazil \\ ${ }^{4}$ Universidade do Estado de Santa Catarina, UDESC-FAED, 88.035-001 Florianópolis, SC, Brazil \\ Correspondence should be addressed to Arthur Schmidt Nanni; arthur.nanni@ufsc.br
}

Received 30 January 2013; Revised 25 April 2013; Accepted 29 April 2013

Academic Editor: Umberta Tinivella

Copyright (C) 2013 Arthur Schmidt Nanni et al. This is an open access article distributed under the Creative Commons Attribution License, which permits unrestricted use, distribution, and reproduction in any medium, provided the original work is properly cited.

Groundwater with anomalous fluoride content and water mixture patterns were studied in the fractured Serra Geral Aquifer System, a basaltic to rhyolitic geological unit, using a principal component analysis interpretation of groundwater chemical data from 309 deep wells distributed in the Rio Grande do Sul State, Southern Brazil. A four-component model that explains $81 \%$ of the total variance in the Principal Component Analysis is suggested. Six hydrochemical groups were identified. $\delta^{18} \mathrm{O}$ and $\delta^{2} \mathrm{H}$ were analyzed in 28 Serra Geral Aquifer System samples in order to identify stable isotopes patterns and make comparisons with data from the Guarani Aquifer System and meteoric waters. The results demonstrated a complex water mixture between the Serra Geral Aquifer System and the Guarani Aquifer System, with meteoric recharge and ascending water infiltration through an intensive tectonic fracturing.

\section{Introduction}

In the last several decades, the global water consumption has dramatically increased, especially for agriculture, water supply, and industrial uses. This paper examines the fluoride content in water from the southernmost region of the fractured subcontinental Serra Geral Aquifer System (SGAS), an important aquifer that supplies a large amount of water for an economic developed region in Southern Brazil.

Fluoride content in water is beneficial to human health and in a moderate concentration $(0.7-1.2 \mathrm{mg} / \mathrm{L})$ prevents dental cavities. When used in excess can be toxic causing human and animal dental and skeletal fluorosis, which has been detected in China [1, 2], India [3], Kenya [4], and Israel [5], among other countries. The drinking water limit recommended by the World Health Organization for fluoride is $1.5 \mathrm{mg} / \mathrm{L}$ [6]. In the study area, the SGAS fluoride average concentrations are around $0.24 \mathrm{mg} / \mathrm{L}$, with a minimum value of $0.02 \mathrm{~m} / \mathrm{L}$ and the highest at $3.03 \mathrm{mg} / \mathrm{L}$.

The SGAS overlies the Guarani Aquifer System (GAS; [7]), which has been the focus of several recent studies due to its spatial extent and storage potential as a transboundary aquifer [8]. The area covered by the SGAS in Brazil, Uruguay, Argentina, and Paraguay is equivalent to $1,200,000 \mathrm{~km}^{2}$ (Figure 1). In Brazil, these groundwater resources should be efficiently managed to protect its water potential and quality. The climate in the study area ranges from subtropical to temperate, with precipitation average of $1,550 \mathrm{~mm} /$ year.

The SGAS reaches its maximum thickness of about $1,800 \mathrm{~m}$ along the central axis of the Parana Basin, located in the Sao Paulo State. In the Rio Grande do Sul State, this aquifer has a wedge shape, ranging from $1,000 \mathrm{~m}$ in the eastern 


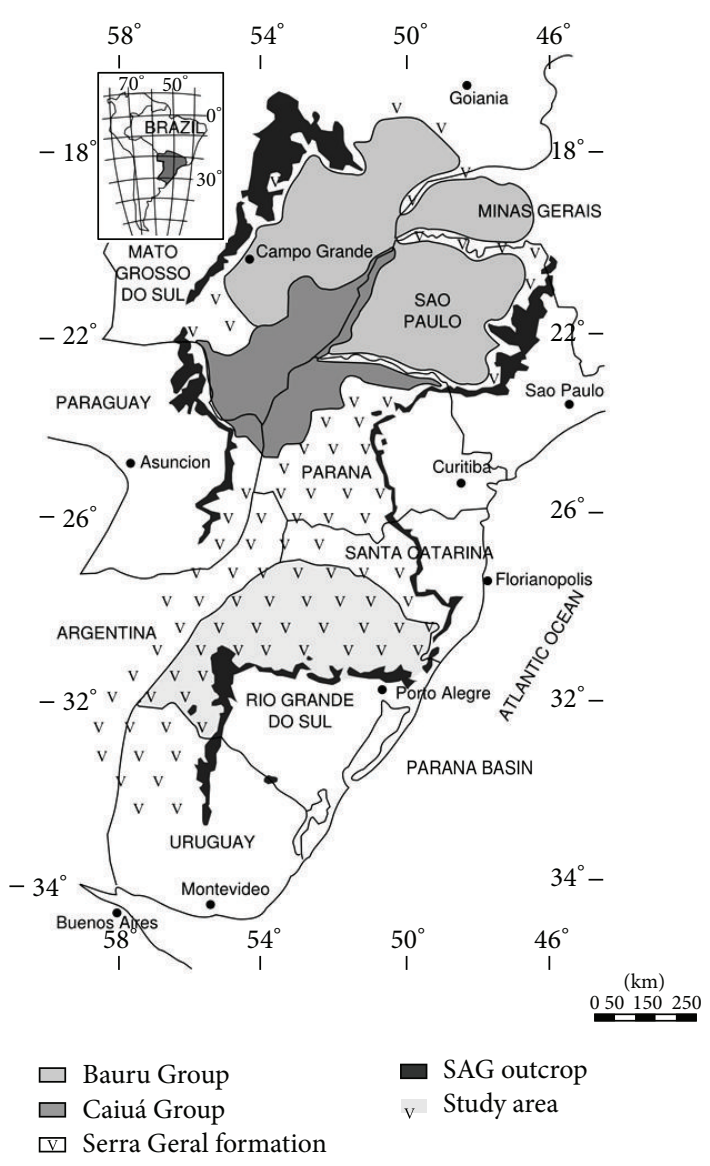

FIgURE 1: Location map showing the Serra Geral Formation (SGF) in South America (modified from [9]).

area bordering the Santa Catarina State to thickness of $200 \mathrm{~m}$ in the western area adjacent to Argentina Border.

The aim of this study is to understand the spatial distribution and geologic control of fluoride content in the SGAS, identifying hydrochemical groups with high fluoride Physicochemical analysis, geostatistics, and stable isotopes approaches were used along with a Geographic Information System (GIS) in order to identify the spatial distribution of the different water types.

1.1. Geologic and Hydrogeologic Framework. The study area is located in the Rio Grande do Sul State, Southern Brazil, and underlies $164,200 \mathrm{~km}^{2}$, extending from $27^{\circ} \mathrm{S}$ to $31^{\circ} \mathrm{S}$ and from $50^{\circ} \mathrm{W}$ to $57^{\circ} \mathrm{W}$. The volcanic sequence has an average thickness of about $550 \mathrm{~m}$ and consists of basaltic to rhyolitic units of Mesozoic age; the last ones occur on the Serra Geral Formation (SGF) top sequence. The clayish soil thickness in the SGF ranges from few decimeters in the eastern area to several meters in the west and northwest. This soil controls water infiltration and, as a consequence, the SGAS recharge by meteoric waters [10].

Studies have suggested groundwater mixing processes between the SGAS and older confined sedimentary aquifer systems from the Parana Basin, including the GAS, through ascending groundwater infiltration [11-16].

Distinct tectonic fracturing occurs in the study area, controlling geomorphological features and groundwater circulation. These structures are directly related to the opening of the South Atlantic Ocean, which is reflected in the major NE and NW fault and fracture directions. Neotectonics is considered to play an important hydrogeological role in the eastern region. Major tectonic systems define individual hydrochemical sectors, which are considered as individual hydrogeological blocks $[15,17,18]$. The tectonic block limited by the Terra de Areia-Posadas and Mata-Jaguari Fault Systems (Figure 2) is uplifted with respect to the neighboring blocks. In the north, the adjacent block is divided into smaller units with a gradual terrain lowering from east to west, influenced by NE normal faults, parallel to the Leao and Perimpo Fault Systems.

The identification of hydrochemical groups in the SGAS is an important tool for the definition of tectonic structures, supporting the fluoride ascending circulation hypothesis in the aquifer [22]. The meteoric recharge pattern as $\mathrm{Ca}^{2+} \mathrm{HCO}_{3}^{-}$waters and also ascending infiltrations by $\mathrm{Na}^{+} \mathrm{HCO}_{3}{ }^{-}$waters with $\mathrm{SO}_{4}{ }^{2-}$ and $\mathrm{Cl}^{-}$in the GAS, resulting in a complex water mixture [15]. Several authors have pointed 


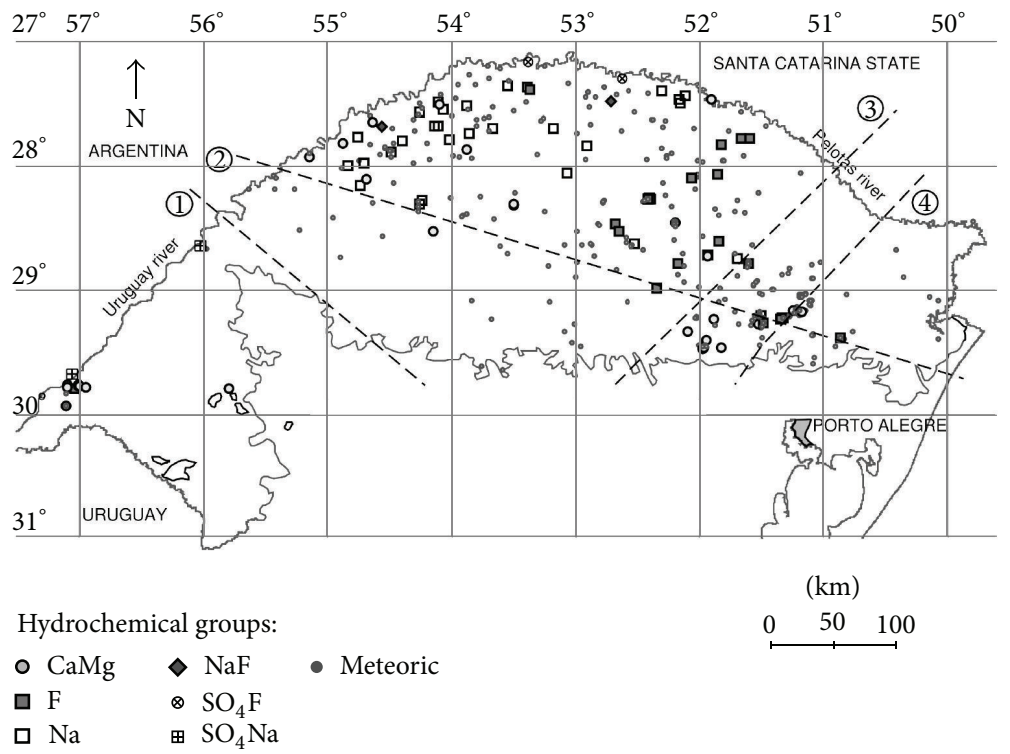

Figure 2: Sample points, hydrochemical groups distribution on SGAS, and major tectonic fault systems: (1), Mata-Jaguari, (2) Terra de Areia-Posadas, (3) Perimpo, and (4) Leao.

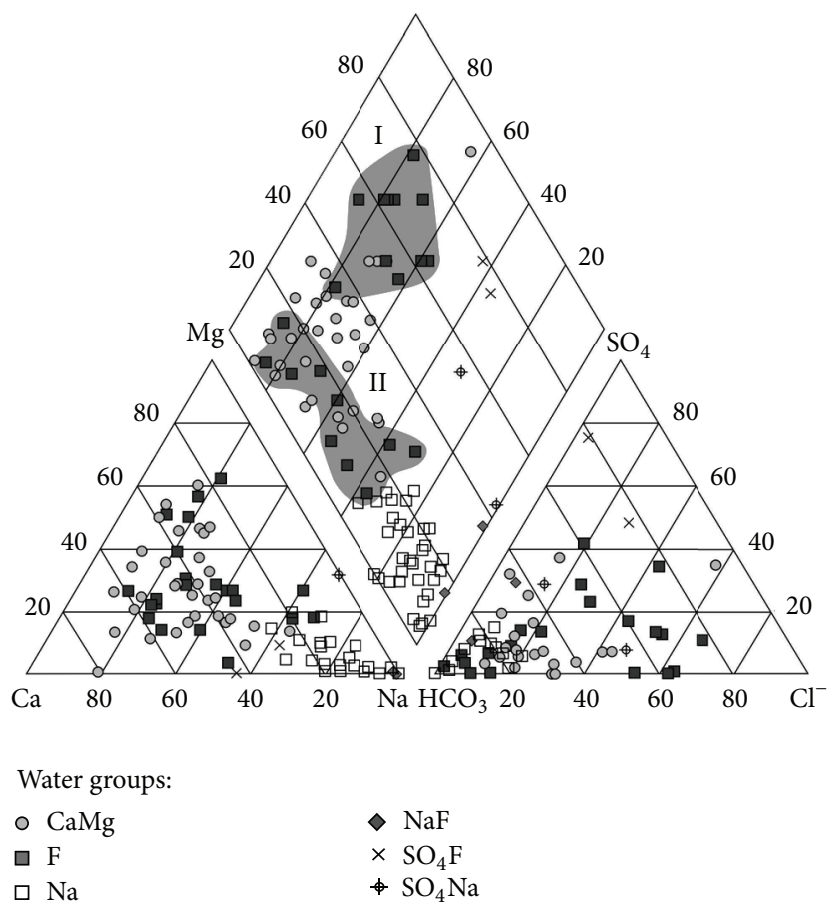

FIGURE 3: Hydrochemical groups distribution in the piper diagram, showing two fluoride hydrochemical types (I-sulfated and IIbicarbonated, [19]).

out that high fluoride content in groundwater can be related to $\mathrm{Na}^{+} \mathrm{HCO}_{3}{ }^{-}$ascending infiltrations waters [11, 15, 22-24]. Such mixing and hydrochemical groups can both result from $\mathrm{Ca}^{2+} \mathrm{HCO}_{3}{ }^{-}$and $\mathrm{Na}^{+} \mathrm{HCO}_{3}{ }^{-}$waters [25].

\section{Materials and Methods}

2.1. Multivariate Statistics. Principal components analysis (PCA) was used to discriminate hydrochemical groups in the 309 physicochemical analyses of the SGAS in order to systematize the interpretation of a large number of variables through the maximization of differences between them [26].

The PCA was performed to 2, 3 , and 4 principal components and normalized to a value of "1," minimum eigenvalue accepted [27]. Subsequently, the outliers were cut by visual analysis in boxplots and dispersion charts for $\mathrm{F}^{-}, \mathrm{Na}^{+}$, $\mathrm{Ca}^{2+}, \mathrm{Mg}^{2+}, \mathrm{HCO}_{3}{ }^{-}, \mathrm{SO}_{4}{ }^{2-}$, and $\mathrm{Cl}^{-}$, considering water classification. This statistical procedure restricts the analysis 


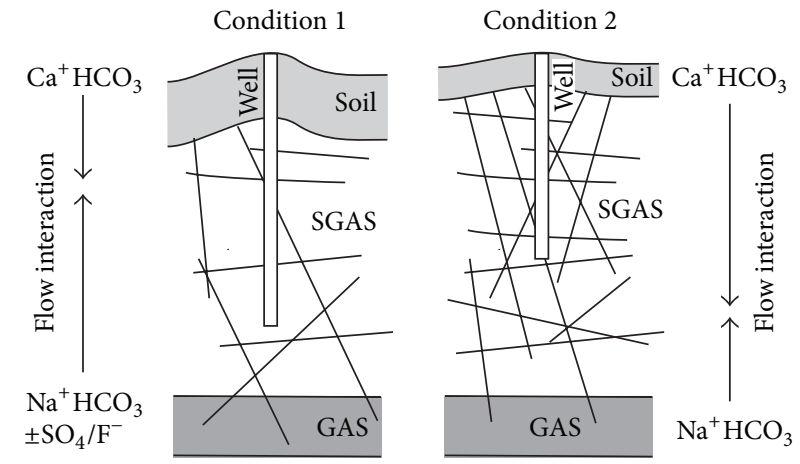

FIGURE 4: Water flow interactions to different geological conditions.

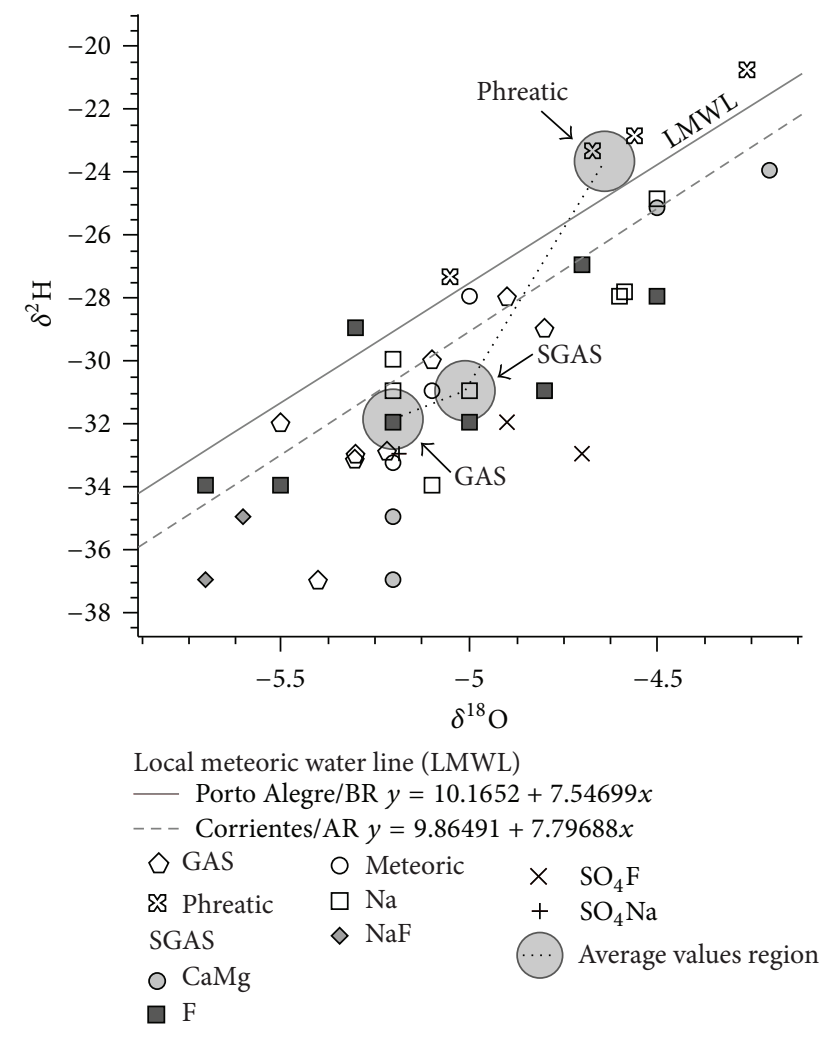

Figure 5: $\delta^{18} \mathrm{O}(\% 0)$ versus $\delta^{2} \mathrm{H}(\%)$ in GAS, SGAS, and phreatic aquifer.

towards the fluoride focus, avoiding interferences from other parameters. The spatial distribution and interpretation of principal components defined by PCA were performed with a GIS environment.

2.2. Stable Isotopes. Stable isotopes were analyzed in the Geochronological Research Center of the Sao Paulo University. The analysis for oxygen was accomplished through the balanced isotopic reaction between water and $\mathrm{CO}_{2}$ over 24 hours.

The $\mathrm{CO}_{2}$ extraction was done in a vacuous line offline and subsequently was read in a Thermo Finnigan Delta Plus/Advantage spectrometer with dual-inlet installed.
TABLE 1: Rotated matrix with four components and characteristic parameters. Data from [21].

\begin{tabular}{lcccc}
\hline \multirow{2}{*}{ Parameters } & \multicolumn{4}{c}{ Components } \\
& 1 & 2 & 3 & 4 \\
\hline $\mathrm{Mg}^{2+}$ & $\mathbf{. 8 7 4}$ & .063 & .072 & .139 \\
$\mathrm{Ca}^{2+}$ & .811 & .231 & -.045 & -.043 \\
$\mathrm{Na}^{+}$ & -.143 & .188 & .870 & .271 \\
$\mathrm{Cl}^{-}$ & .353 & .707 & .206 & -.051 \\
$\mathrm{HCO}_{3}{ }^{-}$ & .572 & .095 &. $\mathbf{6 9 9}$ & -.091 \\
$\mathrm{SO}_{4}{ }^{--}$ & .030 & .872 & .074 & .237 \\
$\mathrm{~F}^{-}$ & .067 &. $\mathbf{1 4 5}$ &. $\mathbf{1 5 0}$ &. $\mathbf{9 5 6}$ \\
\hline Explained variance & 37.433 & 20.260 & 12.694 & 10.770 \\
Cumulative \% of variance & 37.433 & 57.693 & 70.386 & 81.156 \\
\hline
\end{tabular}

The hydrogen was analyzed through the reaction of water with pure zinc at $500^{\circ} \mathrm{C}$ for liberation of the $\mathrm{H}_{2}$ gas.

Twenty seven samples were selected in order to establish stable isotope patterns in the SGAS. These results were considered together with eight additional ones belonging to the GAS (seven data from [28] and one from this study) and four from phreatic waters from an adjacent area [28]. This procedure is appropriate for understanding water mixture features between aquifers and to estimate their relative ages.

Unfiltered water samples were collected and stored in $100 \mathrm{~mL}$ polypropylene bottles to provide adequate volume for separate analyses of $\delta^{18} \mathrm{O}$ and $\delta^{2} \mathrm{H}$. All data considered in this paper are expressed in \%o with respect to Vienna Standard Mean Ocean Water (VSMOW) on the Delta scale:

$$
\delta=\left[\frac{\left(1000+R_{\text {sample }}\right)}{\left(1000+R_{\text {standard }}\right)}-1\right] * 1000
$$

where $R_{\text {sample }}$ is the ${ }^{18} \mathrm{O} /{ }^{16} \mathrm{O}$ or ${ }^{2} \mathrm{H} /{ }^{1} \mathrm{H}$ ratio of the sample and $R_{\text {standard }}$ is the corresponding ratio in VSMOW. Analytical precisions were better than $\pm 0.5 \%$ o for $\delta^{18} \mathrm{O}$ and $\pm 2 \%$ o for $\delta^{2} \mathrm{H}$.

The altitude and the distance from the ocean can influence stable isotopes patterns. The average altitude of the SGAS in the area is $500 \mathrm{~m}$, and the spatial position ranges from the coast in the eastern sector to $800 \mathrm{~km}$ inland in the western sector. 
TABLE 2: Cluster central scores, dominant components and hydrochemical groups. Data from [21].

\begin{tabular}{|c|c|c|c|c|c|c|c|c|c|}
\hline \multirow{2}{*}{ Component } & \multicolumn{9}{|c|}{ Cluster } \\
\hline & 1 & 2 & 3 & 4 & 5 & 6 & 7 & 8 & 9 \\
\hline $\mathrm{CaMg}$ & 1.614 & -0.613 & -0.228 & 0.511 & -0.152 & -0.724 & 2.042 & -0.722 & -1.720 \\
\hline $\mathrm{SO}_{4}$ & 0.987 & 4.411 & -0.377 & -1.198 & -0.113 & 9.303 & -0.236 & -0.260 & -0.348 \\
\hline $\mathrm{Na}$ & -0.892 & 3.032 & -0.881 & -0.667 & -0.305 & -0.845 & 1.092 & 1.653 & 2.691 \\
\hline $\mathrm{F}$ & -0.330 & -1.357 & 1.244 & 6.986 & -0.250 & 2.849 & 0.285 & -0.034 & 4.786 \\
\hline Cases & 22 & 2 & 19 & 3 & 212 & 2 & 11 & 36 & 2 \\
\hline Hydrochemical group & $\mathrm{CaMg}$ & $\mathrm{SO}_{4} \mathrm{Na}$ & $\mathrm{F}$ & $\mathrm{F}$ & Meteoric & $\mathrm{SO}_{4} \mathrm{~F}$ & $\mathrm{CaMg}$ & $\mathrm{Na}$ & $\mathrm{NaF}$ \\
\hline
\end{tabular}

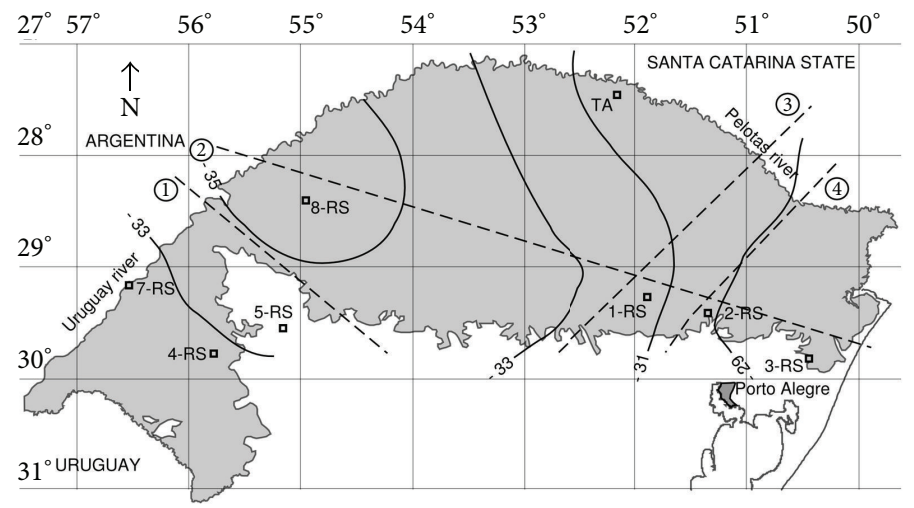

(a)

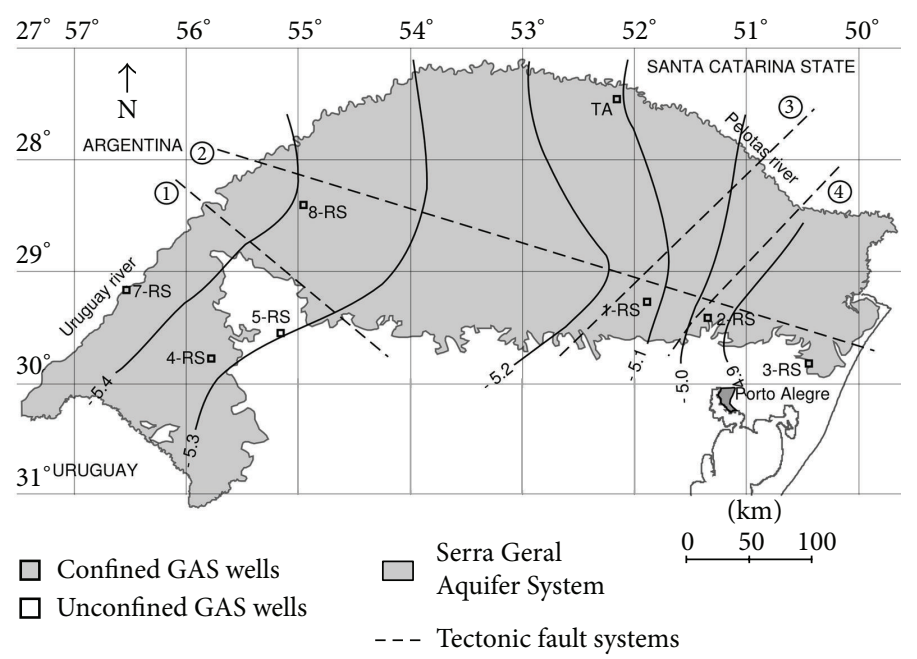

(b)

Figure 6: Hydrogeological spatial trends of $\delta^{2} \mathrm{H}(\mathrm{a})$ and $\delta^{18} \mathrm{O}$ (b) in the GAS (data from [20]) and major tectonic fault systems: (1) MataJaguari, (2) Terra de Areia-Posadas, (3) Perimpo, and (4) Leao.

Due to this, ISOHIS [29] isotope data from the precipitation sampling stations were selected both in Porto Alegre, Southern Brazil, located in coastal and low altitude condition (GNIP code 8396700) and Corrientes, Argentina, located in interior and low altitude (GNIP code 8716600) area showed to compare data obtained in this research.

\section{Results and Discussion}

3.1. Principal Components Analysis. The PCA results show the correspondence of each component to the analyzed parameters. The solution using the eigenvalue criterion results in four components that explain $81 \%$ of the total variance. Component 4 is highly weighted by fluoride (Table 1 ).

Component 1 contains $\mathrm{HCO}_{3}{ }^{-}, \mathrm{Ca}^{2+}$, and $\mathrm{Mg}^{2+}$, typical for calcium and magnesium bicarbonated waters with short to medium residence time. In Component $2, \mathrm{SO}_{4}{ }^{2-}$ and $\mathrm{Cl}^{-}$prevail, indicating calcium and sodium-chlorinated and sulfate waters. Component 3 is distinguished by $\mathrm{HCO}_{3}{ }^{-}$ and $\mathrm{Na}^{+}$, representing sodium bicarbonated waters. The $\mathrm{F}^{-}$ followed by $\mathrm{Na}^{+}$and $\mathrm{SO}_{4}{ }^{2-}$ defines Component 4 , which 


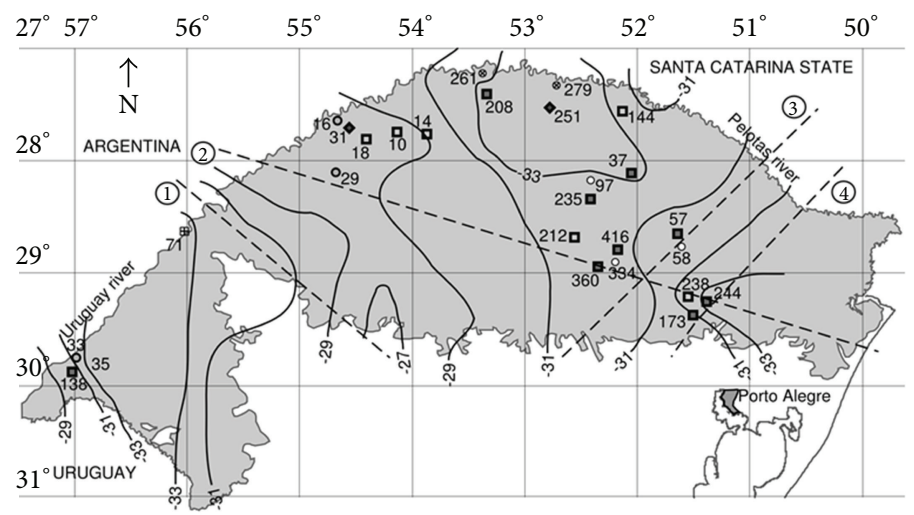

(a)

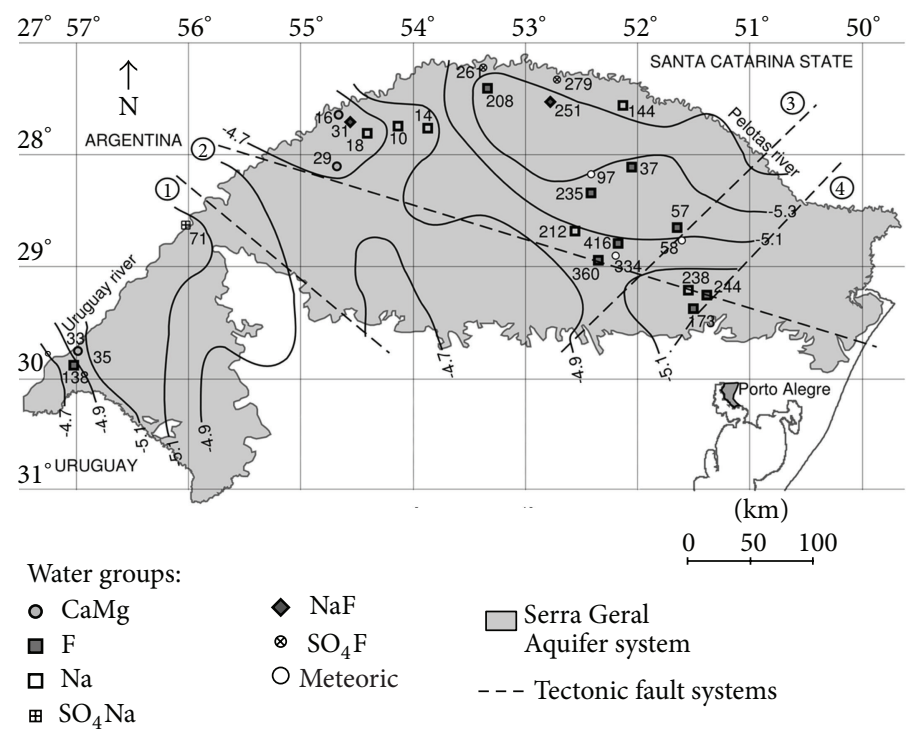

(b)

FIGURE 7: Hydrogeological spatial trends of $\delta^{2} \mathrm{H}(\mathrm{a})$ and $\delta^{18} \mathrm{O}(\mathrm{b})$, hydrochemical groups in the SGAS and major tectonic fault systems: (1), Mata-Jaguari, (2) Terra de Areia-Posadas, (3) Perimpo, and (4) Leao.

comprises the high $\mathrm{F}^{-}$group linked to sodium-sulfated waters.

Based on these components, the solution for nine clusters was selected, and it shows the best approach to the hydrochemical groups. Subsequently, a cluster interpretation was performed based on central scores of each cluster. In order to assist the interpretation, each cluster was renamed according to the predominant ion (Table 2), defining hydrochemical groups. Thus, Component 1 has been renamed to $\mathrm{CaMg}$, Component 2 to $\mathrm{SO}_{4}$, Component 3 to $\mathrm{Na}$, and Component 4 to $\mathrm{F}$.

Clusters 3 and 4 are composed predominantly by the $\mathrm{F}$ group. Clusters 1 and 7 comprise the CaMg group. Cluster 8 is composed by the Na group. Other clusters show prevalence of two components, resulting in the groups $\mathrm{SO}_{4} \mathrm{Na}, \mathrm{SO}_{4} \mathrm{~F}$, and NaF. Cluster 5 comprises the Meteoric waters and other samples with no relationship to the four principal components.
3.2. Hydrochemistry. The geochemical data based on PCA results were plotted in a piper diagram (Figure 3 ), with the four renamed clusters defined by the PCA. The majority of wells (212 out of 309 wells) have a composition close to meteoric waters with $\mathrm{Ca}^{2+} \mathrm{HCO}_{3}{ }^{-}$nature and do not include high fluoride waters. Due to this, 212 samples are not represented in the diagrams in order to obtain a better fit by the other groups.

The CaMg group represents a predominant $\mathrm{HCO}_{3}{ }^{-}$water type where $\mathrm{Mg}^{+2}$ appears in more than $50 \%$ of the wells (Figure 3).

The Na group shows their typical distribution in the piper diagram, representing $\mathrm{Na}^{+} \mathrm{HCO}_{3}{ }^{-}$waters.

$\mathrm{SO}_{4} \mathrm{Na}, \mathrm{SO}_{4} \mathrm{~F}$, and $\mathrm{NaF}$ groups appear only in two wells each. Both wells compose distinct groups as shown in Figure 3.

F distribution in the piper diagram maintains an association with sulfated and bicarbonated groundwaters. These 


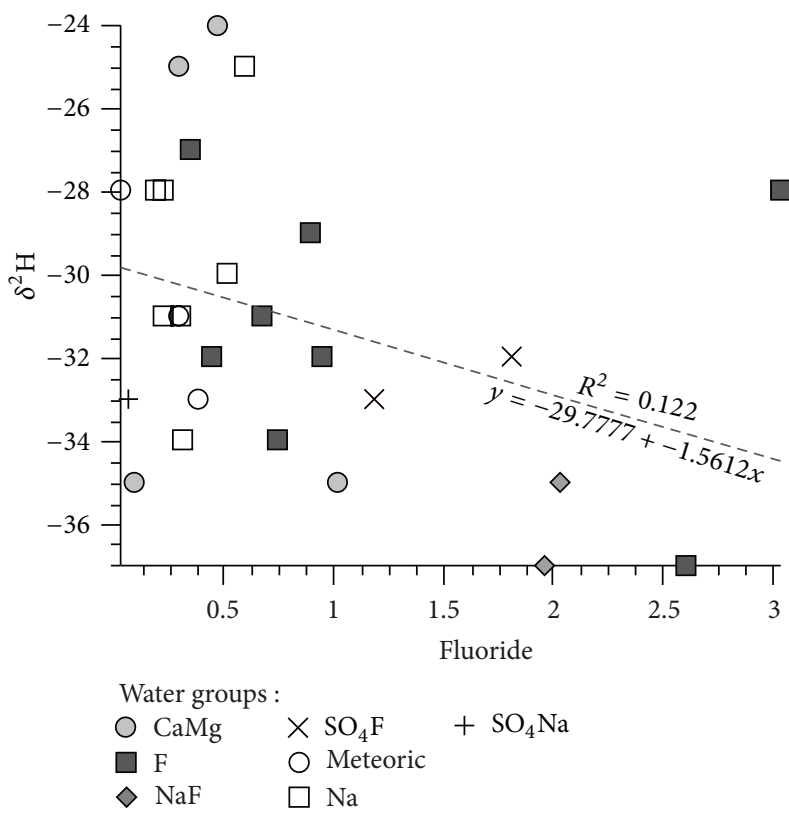

(a)

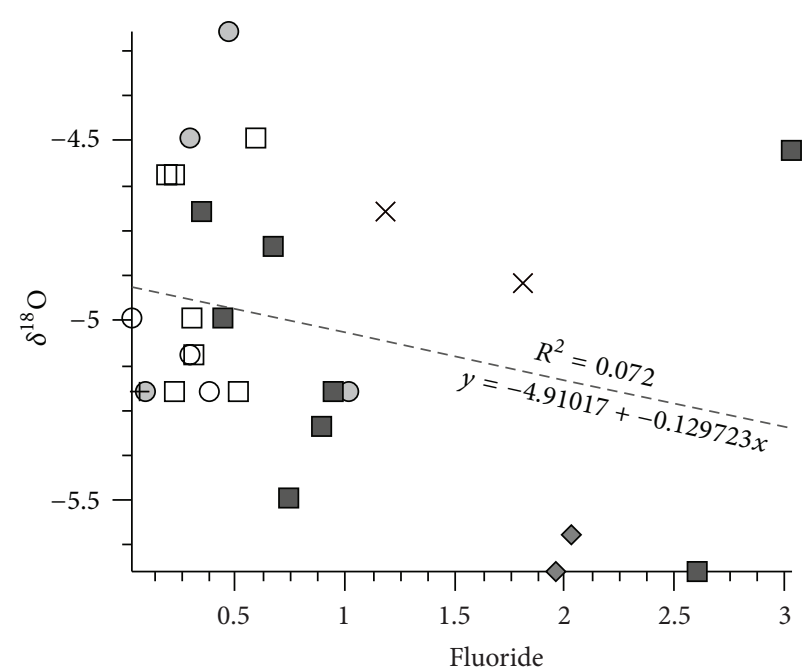

$\begin{array}{ll}\text { Water groups: } & \\ \bigcirc \mathrm{CaMg} & \times \mathrm{SO}_{4} \mathrm{~F}\end{array}+\mathrm{SO}_{4} \mathrm{Na}$

(b)

FIGURE 8: Fluoride versus $\delta^{18} \mathrm{O}$ and $\delta^{2} \mathrm{H}$ and the SGAS hydrochemical groups.

hydrochemical characteristics are also related to different groundwater sources or point out to mixture features during groundwater ascending infiltration, where ionic enrichment including increasing fluoride content can result from the interaction of ascending/descending water recharge due to longer residence time in the $\mathrm{Na}$ and $\mathrm{CaMg}$ hydrochemical groups [19]. Thus, the $\mathrm{SO}_{4} \mathrm{~F}, \mathrm{NaF}, \mathrm{F}$, and $\mathrm{SO}_{4} \mathrm{Na}$ hydrochemical groups have a closed relationship interaction with two or more fracture directions (Figure 4), where $\mathrm{SO}_{4}{ }^{2-}, \mathrm{Na}^{+}$, and fluoride can ascend.

3.3. Stable Isotopes. The 27 analyzed samples from SGAS are distributed among the six water groups defined in the PCA. For GAS waters, one sample was analyzed and aggregated other 7 results [20]. Another 4 results to phreatic waters [28] were aggregated as mentioned. The $\delta^{18} \mathrm{O}(\%)$ ranges from -5.0 to -4.2 (phreatic waters), from -5.7 to -4.2 (SGAS), and from -5.5 to -4.8 (GAS), while the $\delta^{2} \mathrm{H}(\%$ ) varies from -27.4 to -20.8 (phreatic waters), from -37 to -24 (SGAS), and from -37 to -28 (GAS; Table 3). The SGAS shows a scattered distribution compared to the GAS (Figure 5). Nevertheless, the average of $\delta^{18} \mathrm{O}$ and $\delta^{2} \mathrm{H}$ values in both aquifer systems is similar, and the SGAS is located in an intermediate position but nearer to GAS when compared to phreatic waters. This reinforces the hypothesis of water circulation through the SGAS to the GAS, with minor influence of phreatic/meteoric waters in the sampled field.

The GAS data plotted in a map (Figure 6) show decreasing $\delta^{2} \mathrm{H}$ and $\delta^{18} \mathrm{O}$ values from east to west, reflecting the distance from the ocean and the groundwater flow direction through the GAS. The lowest $\delta^{18} \mathrm{O}$ and $\delta^{2} \mathrm{H}$ values in the GAS are related to the highest confinement and distance from direct recharge areas. In this sense, tectonic fractures can provide meteoric to medium residence time waters to the GAS across the Serra Geral Formation, indicating descending water recharge processes, corresponding to Condition 2 described into Figure 4.

The SGAS $\delta^{18} \mathrm{O}$ and $\delta^{2} \mathrm{H}$ results plotted in the same map show a different arrangement from the GAS, with the lowest values in the northern, western, and eastern portions (Figure 7). These differences are related to the influence of tectonic fractures and, as a consequence, to the hydrochemical groups distribution [19].

In the northern region, the lowest $\delta^{18} \mathrm{O}$ and $\delta^{2} \mathrm{H}$ values coincide with a greater volcanic sequence thickness and thicker soils, providing for an increase in groundwater residence time and reduced meteoric water recharge. The prevalence of $\mathrm{SO}_{4} \mathrm{~F}, \mathrm{NaF}$, and $\mathrm{F}$ hydrochemical groups in this portion confirms the long residence time and older relative age to this waters.

In the western sector of Figure 6, samples with the lowest $\delta^{18} \mathrm{O}$ and $\delta^{2} \mathrm{H}$ values are located along the Uruguay River Fault System in an NE-SW direction. In this area, the SGAS is thinner, and the intense tectonic fracturing favors to the groundwater ascension through the confined GAS.

In the eastern area, the lowest $\delta^{18} \mathrm{O}$ and $\delta^{2} \mathrm{H}$ values (samples 238 and 244) are related to the Leao and Terra de Areia-Posadas Fault Systems, which allow for groundwater ascension through the confined GAS.

The scatter diagram of fluoride versus $\delta^{18} \mathrm{O}$ and $\delta^{2} \mathrm{H}$ (Figure 8) reveals, in a broad sense, that lower isotope ratios (most negative values) are associated with higher fluoride content, reflecting water-rock interaction during a long residence time. Similar conditions were also described by [24] in the GAS in the Sao Paulo State, Southern Brazil. This behavior can be associated with ascending infiltration GAS waters. 
TABLE 3: $\delta^{18} \mathrm{O}$ and $\delta^{2} \mathrm{H}$ values of phreatic waters (a), GAS (a), and SGAS (b). Data from [28] $\left({ }^{*}\right)$ and [20] $\left({ }^{* *}\right)$. TA is a code to Tres Arroios City (sampled by author). Fluoride content is exclusive to SGAS.

(a)

\begin{tabular}{lccc}
\hline Sample code & Aquifer & $\delta^{18} \mathrm{O}(\%)$ & $\delta^{2} \mathrm{H}(\%)$ \\
\hline PMT1 $^{*}$ & & -4.67 & -23.4 \\
PMT2 $^{*}$ & Phreatic & -4.26 & -20.8 \\
PMCG3* $^{*}$ & -5.05 & -27.4 \\
PMBF7* $^{*}$ & & -4.56 & -22.9 \\
\hline Averages & & -4.64 & -23.7 \\
\hline TA & & -5.1 & -30.0 \\
1-RS** & -5.2 & -33.0 \\
2-RS & & -4.9 & -28.0 \\
3-RS** & & -4.8 & -29.0 \\
4-RS & & -5.3 & -33.0 \\
5-RS** & & -5.3 & -33.0 \\
7-RS** & GAS & -5.5 & -32.0 \\
8-RS** & & -5.4 & -37.0 \\
\hline Averages & & -5.28 & -33.2 \\
\hline
\end{tabular}

(b)

\begin{tabular}{|c|c|c|c|}
\hline Sample code & SGAS water group & $\mathrm{F}^{-}(\mathrm{mg} / \mathrm{L})$ & $\delta^{18} \mathrm{O}(\% 0)$ \\
\hline 35 & $\mathrm{CaMg}$ & 0.1 & -5.2 \\
\hline 33 & $\mathrm{CaMg}$ & 1.02 & -5.2 \\
\hline 29 & $\mathrm{CaMg}$ & 0.3 & -4.5 \\
\hline 16 & $\mathrm{CaMg}$ & 0.47 & -4.2 \\
\hline 416 & $\mathrm{~F}$ & 0.45 & -5.0 \\
\hline 360 & F & 0.68 & -4.8 \\
\hline 235 & F & 0.95 & -5.2 \\
\hline 208 & F & 0.75 & -5.5 \\
\hline 173 & F & 0.9 & -5.3 \\
\hline 138 & F & 3.03 & -4.5 \\
\hline 57 & $\mathrm{~F}$ & 0.35 & -4.7 \\
\hline 37 & $\mathrm{~F}$ & 2.6 & -5.7 \\
\hline 244 & $\mathrm{Na}$ & 0.32 & -5.1 \\
\hline 238 & $\mathrm{Na}$ & 0.52 & -5.2 \\
\hline 212 & $\mathrm{Na}$ & 0.31 & -5.0 \\
\hline 144 & $\mathrm{Na}$ & 0.23 & -5.2 \\
\hline 18 & $\mathrm{Na}$ & 0.23 & -4.6 \\
\hline 14 & $\mathrm{Na}$ & 0.19 & -4.6 \\
\hline 10 & $\mathrm{Na}$ & 0.6 & -4.5 \\
\hline 251 & $\mathrm{NaF}$ & 1.96 & -5.7 \\
\hline 31 & $\mathrm{NaF}$ & 2.03 & -5.6 \\
\hline 279 & $\mathrm{SO}_{4} \mathrm{~F}$ & 1.19 & -4.7 \\
\hline 261 & $\mathrm{SO}_{4} \mathrm{~F}$ & 1.81 & -4.9 \\
\hline 71 & $\mathrm{SO}_{4} \mathrm{Na}$ & 0.07 & -5.2 \\
\hline 334 & Meteoric & 0.39 & -5.2 \\
\hline 97 & Meteoric & 0.3 & -5.1 \\
\hline 58 & Meteoric & 0.03 & -5.0 \\
\hline Averages & & 0.81 & -5.01 \\
\hline
\end{tabular}

\section{Conclusions}

In the Rio Grande do Sul State, extensive groundwater mixing processes operate between the SGAS and GAS through defined and intense tectonic fractures. Six hydrochemical groups were distinguished in the SGAS, three of them containing substantial fluoride contents in combination with $\mathrm{Na}^{+}$ and $\mathrm{SO}_{4}{ }^{2-}$. Ascending recharge processes are considered to define ionic enrichment, especially in $\mathrm{Na}^{+}, \mathrm{F}^{-}, \mathrm{SO}_{4}{ }^{2-}$, and $\mathrm{Cl}^{-}$.

The comparison between $\delta^{18} \mathrm{O}$ and $\delta^{2} \mathrm{H}$ spatial distribution in the SGAS demonstrates a different scenario concerning the GAS. The differences are probably explained by the interference of different tectonic structures than those in the GAS which are responsible for the defined hydrogeological blocks. The combination of deep fault zones and high pressure and temperature conditions in a confined GAS supports the hypothesis of ascending groundwater infiltration.

The depleted $\delta^{18} \mathrm{O}$ and $\delta^{2} \mathrm{H}$ values suggest that fluoride enrichment in the SGAS is related to percolation through the GAS in confinement and long residence time conditions. The similar values of $\delta^{18} \mathrm{O}$ and $\delta^{2} \mathrm{H}$ in the two aquifer systems suggest, in some regions, that ascending recharge processes are more intense than meteoric recharge. In the Rio Grande do Sul State, this behavior increases from east to west, which is the groundwater flow direction in the GAS. Similar behavior is observed in the SGAS, except in some scarps and valleys, as is demonstrated by the distribution of the $\mathrm{CaMg}$ water group. The fluoride input to the groundwater is probably related to water-rock interaction in the GAS and in older aquifer systems below it.

\section{Acknowledgments}

The funding for this study was provided by the Brazilian National Research Council (CNPq), Rio Grande do Sul Research Foundation (Fapergs), and Rio Grande do Sul Environmental Agency (Fepam).

\section{References}

[1] N. Lin, J. Tang, and J. Bian, "Geochemical environment and health problems in China," Environmental Geochemistry and Health, vol. 26, no. 1, pp. 81-88, 2004.

[2] W. Genxu and C. Guodong, "Fluoride distribution in water and the governing factors of environment in arid north-west China," Journal of Arid Environments, vol. 49, no. 3, pp. 601-614, 2001.

[3] V. Vijaya Kumar, C. S. T. Sai, P. L. K. M. Rao, and C. S. Rao, "Studies on the distribution of fluoride in drinking water sources in Medchal Block, Ranga Reddy District, Andhra Pradesh, India," Journal of Fluorine Chemistry, vol. 55, no. 3, pp. 229-236, 1991.

[4] W. K. Moturi, M. P. Tole, and T. C. Davies, "The contribution of drinking water towards dental fluorosis: a case study of Njoro division, Nakuru district, Kenya," Environmental Geochemistry and Health, vol. 24, no. 2, pp. 123-130, 2002.

[5] U. Kafri, A. Arad, and L. Halicz, "Fluorine occurrence in groundwater in Israel and its significance," Journal of Hydrology, vol. 106, no. 1-2, pp. 109-129, 1989. 
[6] WHO, Fluorides, Environmental Health Criteria no. 227, United Nations Environmental Programme, International Labour Organization, World Health Organization, Geneva, Switzerland, 2002.

[7] H. C. N. S. Campos, "Modelación conceptual y matemática del acuífero guaraní, Cono Sur," Acta Geológica Leopoldensia, vol. 23, no. 4, pp. 3-50, 2000.

[8] L. M. Aráujo, A. B. França, and P. E. Potter, "Hydrogeology of the Mercosul aquifer system in the Paraná and Chaco-Paraná Basins, South America, and comparison with the NavajoNugget aquifer system, USA," Hydrogeology Journal, vol. 7, no. 3, pp. 317-336, 1999.

[9] A. Batezelli, A. R. Saad, V. J. Fulfaro, A. C. Corsi, P. M. B. Landim, and J. A. J. Perinotto, "Análise de bacia aplicada às unidades mesozoicas do triângulo mineiro (sudeste do Brasil): uma estratégia na prospecção de recursos hídricos subterrâneos," Águas Subterrâneas, vol. 19, no. 1, pp. 61-73, 2005.

[10] P. A. R. Reginato and A. J. Strieder, "Integração de dados geológicos na prospecção de aqüíferos fraturados na Formação Serra Geral," Revista Águas Subterrâneas, vol. 20, no. 1, pp. 1-14, 2006.

[11] M. Szikszay, J. Teissedre, U. Barner, and E. Matsui, "Geochemical and isotopic characteristics of spring and groundwater in the State of São Paulo, Brazil," Journal of Hydrology, vol. 54, no. 1-3, pp. 23-32, 1981.

[12] G. Fraga, Origem de fluoreto em águas subterrâneas dos Sistemas Aqüiferos Botucatu e Serra Geral da Bacia do Paraná [Ph.D. thesis], Programa de Pós-Graduação em Recursos Minerais e Hidrogeologia, Universidade de São Paulo, 1992.

[13] C. V. Portela Filho, F. J. F. Ferreira, E. F. Rosa Filho, A. C. Buchmann, and S. P. Rostirolla, "Estudo preliminar da conexão entre os aquíferos Serra Geral e Guarani com base em dados aeromagnetométricos e hidroquímicos," in XII Congresso Brasileiro de Águas Subterrâneas, vol. 1, pp. 74-86, Editora da ABAS, São Paulo, Brazil, 2002.

[14] C. V. Portela Filho, F. J. F. Ferreira, E. F. Rosa Filho, A. C. Buchmann, and S. Rostirolla, "Compartimentação magnética-estrutural do sistema aquífero Serra Geral e sua conectividade com o Sistema Aqüífero Guarani na região central do arco de Ponta Grossa (Bacia do Paraná)," Revista Brasileira de Geociências, vol. 3, pp. 369-381, 2005.

[15] J. L. F. Machado, Compartimentação espacial e arcabouço hidroestratigráfico do Sistema Aqüífero Guarani no Rio Grande do Sul [Ph.D. thesis], Programa de Pós-Graduação em Geologia-Área de Concentração em Geologia Sedimentar, Universidade do Vale do Rio Dos Sinos, São Leopoldo, Brazil, 2005.

[16] L. F. Scheibe and R. Hirata, "O contexto tectônico dos sistemas aqǘferos guarani e serra geral em santa catarina: uma revisão," in XV Congresso Brasileiro de Águas Subterrâneas, pp. 1-14, Associação Brasileira de Águas Subterrâneas, Curitiba, Brazil, 2008.

[17] N. A. Lisboa, Fácies, estratificações hidrogeoquímicas e seus controladores geológicos, em unidades hidrogeológicas do Sistema Aqüifero Serra Geral, na Bacia do Paraná, Rio Grande do Sul [Ph.D. thesis], Curso de Pós-Graduação em Geociências, Universidade Federal do Rio Grande do Sul, 1996.

[18] N. A. Lisboa and E. Menegotto, "Diferenciações hidrogeoquímicas no sistema aqǘfero Serra Geral no Rio Grande do Sul," in XII Simpósio Brasileiro de Recursos Hídricos, pp. 489-496, 1997.

[19] A. Nanni, A. Roisenberg, M. P. C. Marimon, and A. P. Viero, "The hydrochemical facies and anomalous fluoride content in the Serra Geral aquifer system, southern Brazil: a GIS approach with tectonic and principal component analysis," Environmental Geology, vol. 58, no. 6, pp. 1247-1255, 2009.

[20] A. A. Kimmelmann e Silva, A. C. Reboucas, and M. M. F. Santiago, " ${ }^{14} \mathrm{C}$ analyses of groundwater from the Botucatu Aquifer System in Brazil”, Radiocarbon, vol. 31, no. 3, pp. 926-933, 1989.

[21] A. Nanni, A. Roisenberg, J. M. G. Fachel, G. Mesquita, and C. Danieli, "Fluoride characterization by principal component analysis in the hydrochemical facies of Serra Geral Aquifer System in Southern Brazil," The Anais da Academia Brasileira de Ciências, vol. 80, no. 4, pp. 693-701, 2008.

[22] O. A. B. Licht, A geoquímica multielementar na gestão ambiental-identificação e caracterização de províncias geoquímicas naturais, alterações antrópicas da paisagem, áreas favoráveis à prospecção mineral e regiões de risco para a saúde no estado do Paraná, Brasil [Ph.D. thesis], Pós-Graduação em Geologia, Área de Concentração-Geologia Ambiental, Setor de Ciências da Terra, Universidade Federal do Paraná, Curitiba, Brazil, 2001.

[23] A. V. L. Bittencourt, E. F. Rosa Filho, E. C. Hindi, and A. C. Buchmann Filho, "A influência dos basaltos e de misturas com águas de aquíferos sotopostos nas águas subterrâneas do Sistema Aqüífero Serra- Geral na bacia do rio piquiri, ParanáBR,” Revista Águas Subterrâneas, vol. 17, pp. 67-75, 2003.

[24] O. Sracek and R. Hirata, "Geochemical and stable isotopic evolution of the Guarani Aquifer System in the state of São Paulo, Brazil," Hydrogeology Journal, vol. 10, no. 6, pp. 643-655, 2002.

[25] E. F. Rosa Filho, J. X. Montano, and U. Duarte, "Estudo do movimento das águas subterrâneas do Sistema Aqüífero Guarani (SAG) através de isótopos, no Paraná, São Paulo e no Uruguai," Revista Latino Americana de Hidrogeologia, pp. 109-121, 2007.

[26] A. O. Invernizzi and S. M. B. Oliveira, "Hydrochemical characterization of a watershed through factor analysis," Revista de Águas Subterrâneas, vol. 18, pp. 67-77, 2004.

[27] H. F. Kaiser, "The varimax criterion for analytic rotation in factor analysis," Psychometrika, vol. 23, no. 3, pp. 187-200, 1958.

[28] M. P. Marimom, Origem das Anomalias de Fluoreto nas Águas Subterrâneas utilizadas para abastecimento público da Formação Santa Maria, Estado do Rio Grande do Sul, Brasil [Ph.D. thesis], Curso de Pós-graduação em Geociências, Universidade Federal do Rio Grande do Sul, Porto Alegre, Brazil, 2006.

[29] IAEA-International Atomic Energy Agency, Isotope Hydrology Information System, the ISOHIS Database, 2004, http:// isohis.iaea.org. 

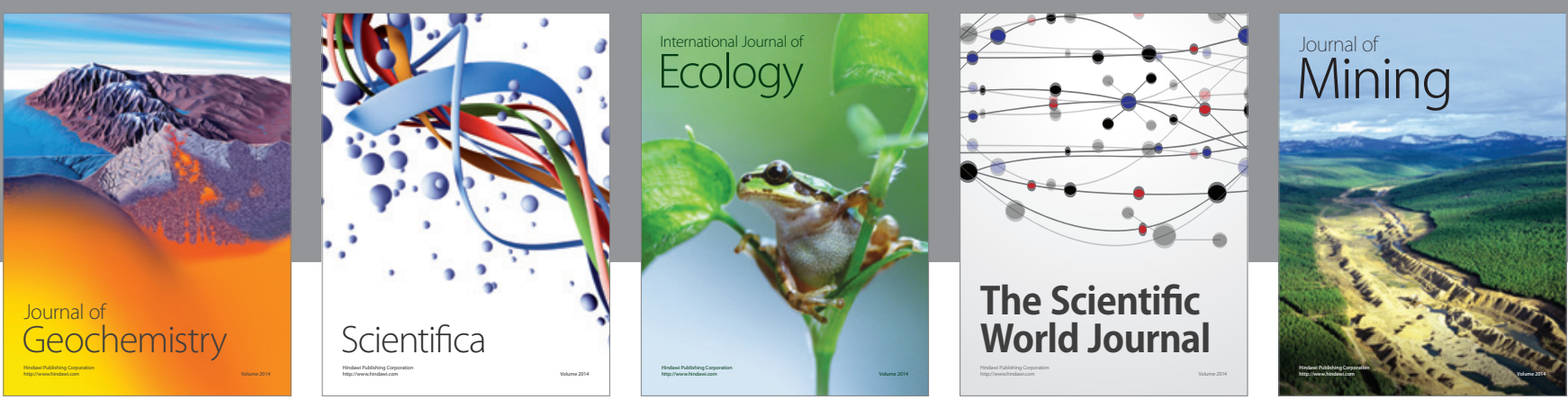

The Scientific World Journal
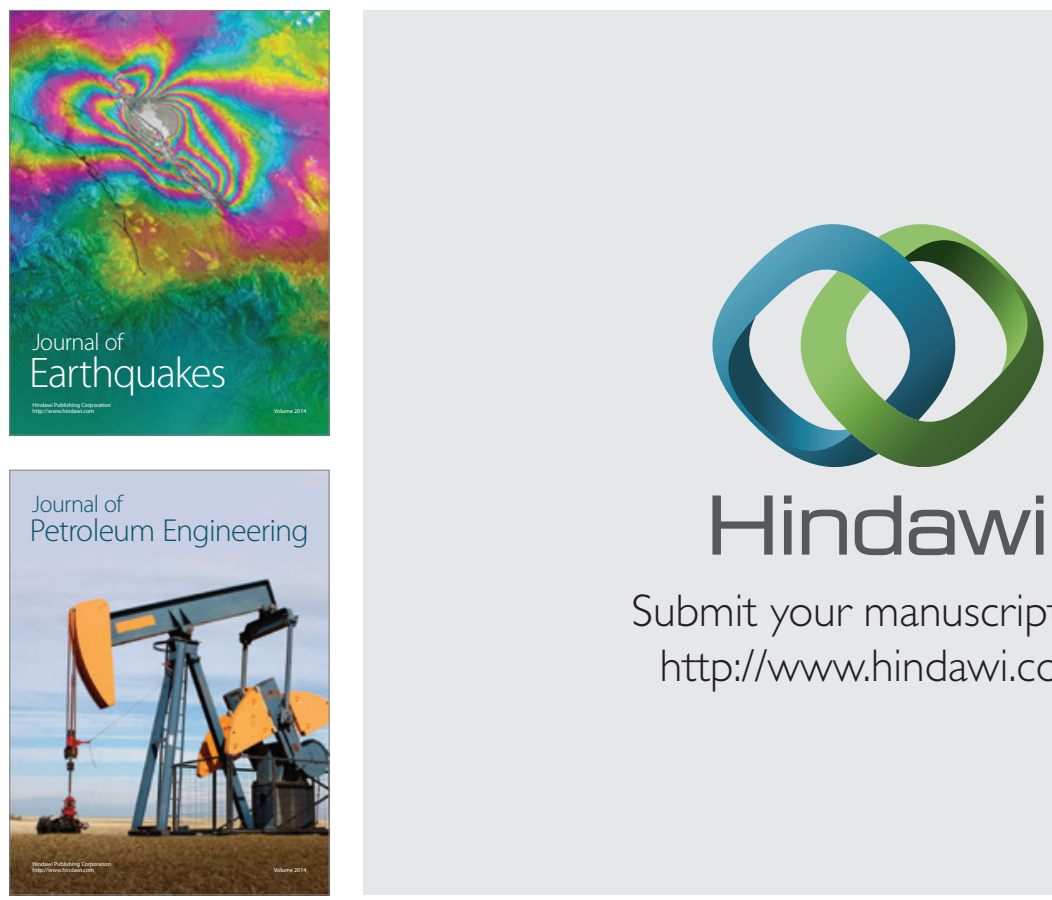

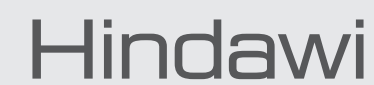

Submit your manuscripts at

http://www.hindawi.com
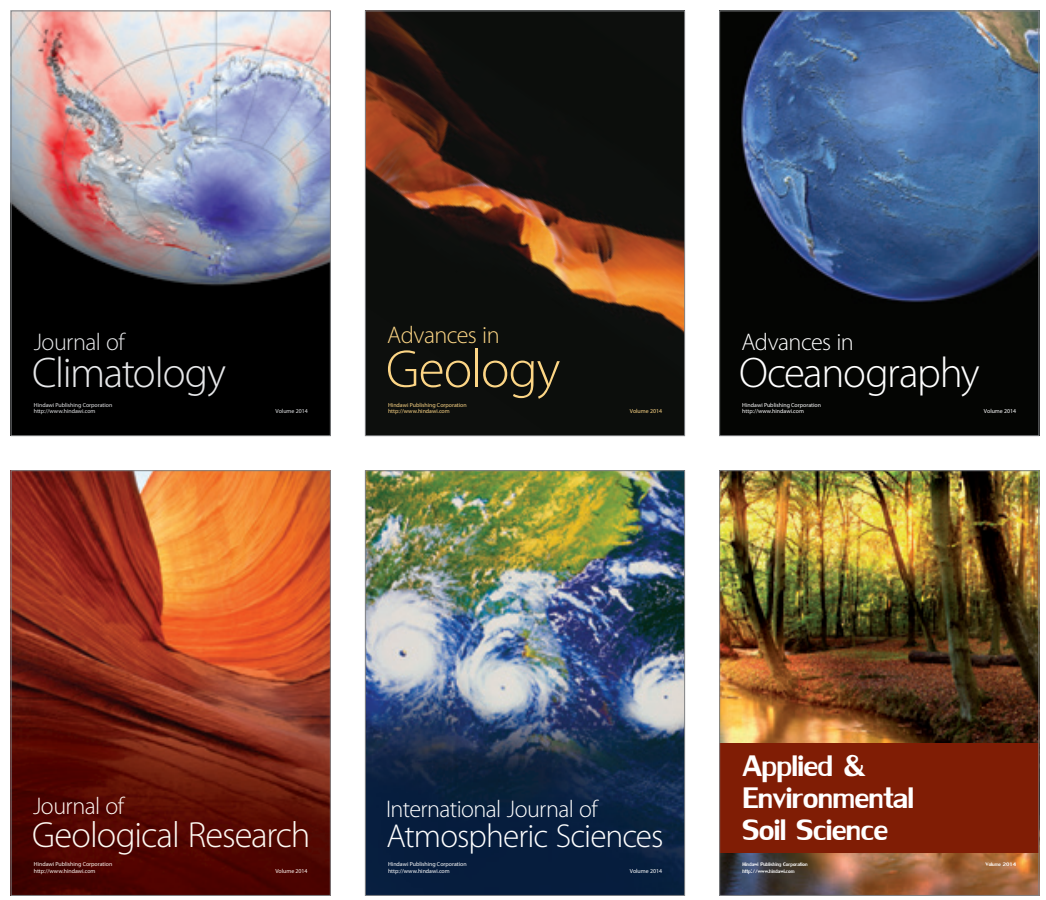
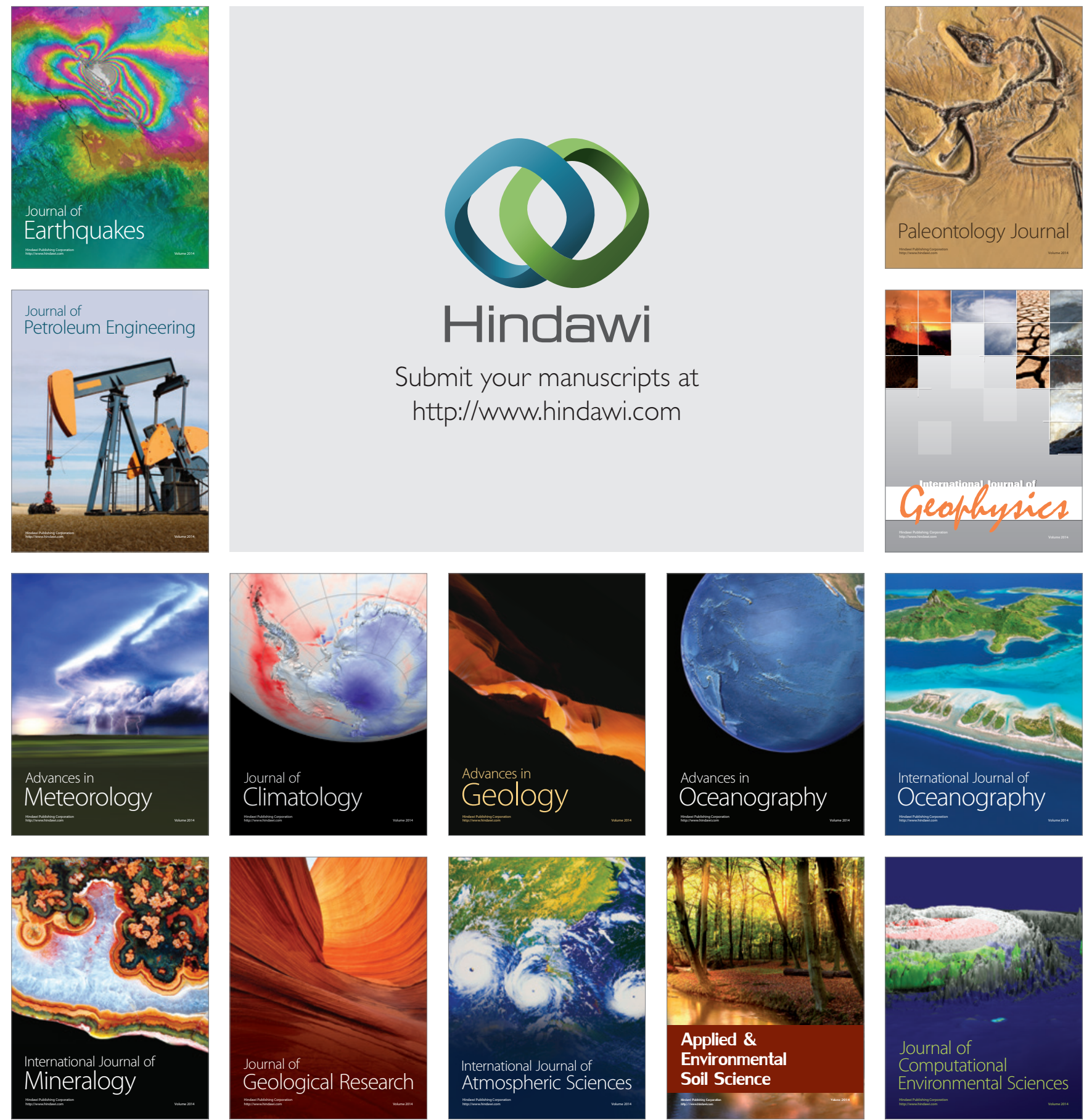